\title{
On Teaching Problem Solving in School Mathematics
}

ErkKi PehKonen ${ }^{\star 1}$, LiISA NÄVERI ${ }^{2}$, AND ANU LAINE ${ }^{3}$

$\approx$ The article begins with a brief overview of the situation throughout the world regarding problem solving. The activities of the ProMath group are then described, as the purpose of this international research group is to improve mathematics teaching in school. One mathematics teaching method that seems to be functioning in school is the use of open problems (i.e., problem fields). Next we discuss the objectives of the Finnish curriculum that are connected with problem solving. Some examples and research results are taken from a Finnish-Chilean research project that monitors the development of problem-solving skills in third grade pupils. Finally, some ideas on "teacher change" are put forward. It is not possible to change teachers, but only to provide hints for possible change routes: the teachers themselves should work out the ideas and their implementation.

Keywords: Mathematics teaching; Open problems; Problem solving

$1 \quad{ }^{\star}$ Corresponding Author. Department of Teacher Education, University of Helsinki, Finland erkki.pehkonen@helsinki.fi

2 Department of Teacher Education, University of Helsinki, Finland

3 Department of Teacher Education, University of Helsinki, Finland 


\section{O poučevanju reševanja problemov $\mathrm{v}$ šolski matematiki}

Erkki PehkoneN*, LiIsA Näveri ANd ANu LAine

$\approx$ Začetek članka je posvečen pregledu razmer v svetu glede reševanja problemov. Nato so opisane dejavnosti skupine ProMath; namen te mednarodne raziskovalne skupine je izboljšanje pouka matematike $\mathrm{v}$ šoli. Metoda, ki bi lahko funkcionirala $\mathrm{v}$ šoli, je uporaba odprtih problemov (tj. problemska polja). Sledi razprava o ciljih finskega kurikuluma, ki so povezani z reševanjem problemov. Nekateri primeri so vzeti iz finsko-čilenskega raziskovalnega projekta, ki spremlja razvoj kompetenc reševanja problemov pri učencih tretjega razreda. Na koncu je podanih nekaj idej glede »spreminjanja učiteljev«. Ni namreč mogoče spremeniti učiteljev, mogoče je podati le namige za spremembo razmišljanja učitelji bi morali sami poiskati ideje in način izvedbe.

Ključne besede: poučevanje matematike, odprti problemi, reševanje problemov 
Problem solving has a long tradition in school mathematics, and has many facets and characterisations. In order to facilitate understanding, we therefore begin by providing a definition of problem solving (cf. Kantowski, 1980): a situation is said to be a problem when an individual must combine (for him/her) new information in a (for him/her) new way in order to solve the problem. If the individual can immediately recognise the procedures needed, the situation is a standard task (or a routine task or exercise). The term non-standard task is often used in reference to a task that one cannot usually find in mathematics books.

\section{An Overview Of Problem-Solving Research}

Since the United States is still the pioneer in the development of mathematics teaching, we will begin with the advances there. Schröder and Lester (1989), for instance, introduced three aims for using problem solving in mathematics teaching. They pointed out that problem solving should not be considered only as teaching content, but also as a teaching method. Later, in Standards for School Mathematics (NCTM, 2000), problem solving is mentioned as a teaching method with which one can improve the quality of mathematics teaching in school.

The key ideas of problem solving seem to have spread around the world, as we can see in the published overview papers. In the last ten years, a number of overview papers have been published in which the situation of problem solving has been described in several countries. The Proceedings of the ICME-9 Topic Study Group (Pehkonen, 2001), for example, is a compound of overview papers regarding problem solving from different continents. In this compound, the development of problem solving in all of the countries covered seems to be very similar. The collection of Törner, Schoenfeld and Reiss (2007) contains a description of problem solving in 15 countries, providing an even better account of the development.

\section{One step further: open problem solving}

When the constructivist view of learning was accepted in mathematics education about 30 years ago, there was a need to develop teaching methods that corresponded to the challenges set by constructivism. One such solution was the open approach (or the use of open problems) in Japan.

In Japan, the so-called open approach to mathematics teaching was developed in the 1970s. It was aimed at developing pupils' creativity and encouraging meaningful discussion in the classroom (Becker \& Shimada, 1997; Pehkonen, 
1995; Shimada, 1977, cf. Nohda, 1991). At the same time, so-called investigations were introduced and accepted as part of mathematics teaching in England, and soon became very popular (Wiliam, 1994). The notion of investigations was disseminated through the Cockcroft Report (1982) in particular. The idea of using open tasks in the classroom therefore spread throughout the world in the $1980 \mathrm{os}$ and 1990s, and research on the potential of open tasks in mathematics education was very lively in many countries (e.g., Clarke \& Sullivan, 1992; Kwon, Park, \& Park, 2006; Mason, 1991; Nohda, 1988; Pehkonen, 1989; Silver, 1995; Stacey, 1995; Williams, 1989; Zimmermann, 1991).

Almost 20 years ago, a number of articles critical of the use of open tasks were published. One American mathematician, for instance, wrote a very sceptical paper on learning mathematics with open problems (Wu, 1994), criticising the way open problems were used in Californian schools. At an international PME conference, Paul Blanc strongly criticised the implementation of investigations in British schools (Blanc \& Sutherland, 1996), reproaching teachers for developing a new mechanical routine to solve investigations.

Using open tasks, we can respond to the challenges of developing mathematics teaching. Such teaching leads almost automatically to problem-centred teaching and clearly increases communication in class, thus approaching instruction that is more open and pupil-centred. Some ten years ago, Pehkonen (2004) wrote an overview on the situation of open problem solving. Later, Zimmermann (2010) described the development of open problem solving over the previous 20 years in Germany, while ProMath meetings have produced research results on the use of open problems for approximately 15 years (e.g., Bergqvist, 2012).

\section{New approaches to teaching mathematics}

Mathematics is not only calculation; the aim of teaching should also be the development of understanding and mathematical thinking. School teaching has been accused of viewing the act of teaching and the context in which it takes places entirely differently. However, psychological studies have shown that learning (even of mathematics) is strongly situation-bound (e.g., Bereiter, 1990; Brown, Collins, \& Duguid, 1989; Collins, Brown, \& Newman, 1989). Studies in learning psychology have, for instance, confirmed the hypotheses of Anderson (1980) that the learning of facts and procedures takes place with various mechanisms (e.g., Bereiter \& Scardamalia, 1996). New elements should therefore be added to mathematics teaching in school.

Traditional teaching is well suited to the learning of facts, but new methods - emphasising, for example, pupils' self-regulated learning - are needed for 
learning procedures. Open learning environments offer such an opportunity, as within them real problems can be dealt with; pupils respond to the problems actively and learning takes place in natural situations. Learning arises through independent investigations and seeking solutions. It is believed that active learning of this kind leads to a better understanding of key principles and concepts. Active working sets a pupil in a real problem-solving environment and can thus combine the phenomena of real life and the classroom (cf. Blumenfeld, Soloway, Marx, Krajeik, Guzdial, \& Palinscsar, 1991).

The development and formulation of ideas, pondering problem situations and balancing alternatives, require discussions between pupils and social interaction. This essential aspect of self-regulated active working is, in our culture, a natural way to rework ideas, conceptions and beliefs (cf. Brown et al., 1989). School culture has typically been characterised by a restriction of discussion; according to learning studies, however, free discussion amongst pupils should be encouraged and not inhibited. The only problem is how to guide the discussion in the right direction and keep it within reasonable bounds.

\section{Open Problems In Focus (The Promath Group)}

In this section, we will give a short description of the history of the ProMath group. The emphasis of the group is on open problems and the open approach in mathematics teaching, with the key question being how to use them.

\section{A brief history of ProMath}

More than ten years ago, the working group ProMath (Problem Solving in Mathematics) was established by a group of Finnish and German professors in mathematics education. A spontaneous meeting at the University of Bielefeld in 1999 can be considered to be the starting point for the series of ProMath workshops. At that meeting, the members decided to meet annually, and to establish the focus of the working group as follows:

the aim of the ProMath group is to study and examine those mathematical-didactical questions which arise through research on the implementation of open problem solving in school.

The research group was designed to be open to everyone interested in mathematical problem solving. The group is based on voluntary organisation and strives to be as democratic as possible, e.g., there is no chair and each year the group votes where the next year's meeting will take place. Usually, the 
location hosting the annual meeting will publish proceedings in which the participants' papers are peer reviewed.

The ProMath group has now been active for more than ten years in Europe, holding annual meetings at various universities. As a rule, ProMath workshops take place at the beginning of autumn (i.e., August/September), and locations have circulated in the following countries (in alphabetical order): Finland, Germany, Hungary, Slovakia, Slovenia, Sweden. The list of all of the participants to date provides a boarder picture, as they originate from nine different countries (in alphabetical order): Australia (1), Denmark (1), Finland (15), Germany (9), Greece (1), Hungary (5), Slovakia (2), Slovenia (2), Sweden (2) and USA (1). Approximately ten presentations are given at each annual meeting.

When reading through the ProMath proceedings of the first ten years, one gains the impression that at the beginning of the 2000 s there were more empirical studies focused on using examples of open problems. In recent years (since the end of the 20oos), the number of general theoretical papers has increased, i.e., there are some papers that could only marginally be regarded as problem solving. Another change concerns the number of examples: during the last few years, the number of examples of open problems has reduced significantly. Consequently, the proceedings of the workshops no longer function as a treasure trove for teaching open problems in school. For the development of school teaching, however, both aspects are needed: examples and theory.

\section{On the use of the open approach}

In line with the aim of the group (see above), the focus of ProMath workshops is open problems and their implementation in school. We therefore begin here with the concept of the 'open approach'.

One method, accepted all over the world, for a teacher to help pupils with optimal learning environments is the so-called open approach. In order to implement this method, which was developed in the 1970s in Japan (Becker \& Shimada, 1997; Shimada, 1977, cf. also Nohda, 1991), one can use so-called open tasks. Such tasks have proved to be a promising solution for developing a proper learning environment, and appear to provide an opportunity for the meaningful teaching and learning of mathematics (cf. Boaler, 1998).

Amongst others, open problems include tasks from everyday life, problem posing, problem fields (or problem sequences), problems without a question, problem variations (the "what if" method), project work and investigations (cf. Pehkonen, 1995; Pehkonen, 1997; Schupp, 2002). For investigations, a starting situation is typically given within which the pupil first formulates 
a problem and then solves it. Such tasks are used extensively in England and Scotland, for example, as well as in Australia.

\section{Problem fields}

Investigations can be divided into two groups: structured and non-structured investigations. The latter are used in England: a pupil is given a starting situation and some starting problems, and then continues independently. Structured investigations are called problem fields (or problem domains). In this case, the teacher prepares a number of extension questions (problems) in advance and, depending on the solution activity of the class, decides which direction pupils will take and how far they will work with the given problem situation.

The purpose of using investigations is to promote pupils' creativity, and especially their divergent thinking (e.g., Kwon et al., 2006). In addition to problem solving, investigations also practise problem posing, as the pupil can, within the framework of the investigation, formulate and solve his/her own problem. When using open tasks in mathematics instruction, pupils have an opportunity to work like an active mathematician (Brown, 1997). It is also important for teachers to have experience with open problems during their education (cf. Zaslavsky, 1995).

\section{Ideas for reforming mathematics teaching by Walsch}

We will next consider the internal reform of mathematics education undertaken in East Germany commencing in the 1980s, which aimed at improving the quality of teaching within the existing curriculum (Walsch, 1984). The purpose was to move away from the method of model learning and towards the development of problem-solving thinking. According to Walsch (1984), didactic studies in East Germany showed that $85 \%$ of all tasks dealt with in mathematics lessons could be solved with a model known to the pupil. The reform was planned to be implemented "through working with tasks", i.e., the central idea was to deal with learning topics in the form of problems. Thus the central idea of the reform could be summarised as: Ordinary mathematics tasks will be dealt with in an unordinary form! (ibid) The following example demonstrates the idea.

Example 1. When the class is calculating the perimeter and area of a rectangle, the teacher can ask pupils to investigate whether the following statements are true or not (through experimenting, drawing, concluding logically, etc.):

- Two rectangles that have the same perimeter always have the same area.

- If the area of a rectangle is enlarged its perimeter will also always get longer.

- For each rectangle there is another rectangle that has the same area but a longer perimeter. 


\section{On teaching problem solving in Finland}

The purpose of mathematics learning for all age groups in Finland is the understanding of mathematical structures and the development of mathematical thinking, not merely mastering mechanical calculations (NBE, 2004). In order to develop correct learning habits, this should be the objective from the very beginning (Grade 1), as knowledge that is based on understanding can be more easily transferred to other contexts (cf. Sierpinska, 1994). According to the Finnish curriculum, it is not sufficient for pupils to be able to calculate mechanically, they should also be capable of providing reasoning and drawing conclusions, as well as being able to explain their activity verbally and in writing (NBE, 2004).

In the foundation of the kindergarten curriculum (NBE, 2010), it is already stated that in the development of mathematical thinking it is important that children learn to observe their own thinking. Children should be challenged to explain what they think and how they think, as well as to justify their thinking.

\section{Some examples from the Finnish-Chilean comparison study}

The three-year Finnish-Chilean comparison study has been financed in 2010-13 by the Academy of Finland (project \#1135556) and CONICYT in Chile (project AKA 09). Its aim is to clarify the development of grade 3-5 pupils' mathematical understanding and problem-solving skills when using open problem tasks at least once a month. More details on the research project are available in, for example, the published paper (Laine, Näveri, Pehkonen, Ahtee, \& Hannula, 2012).

Example 2. The task "Divide a Square", implemented in November 2010, was the second experimental task: "Divide a square into two identical pieces. In how many different ways can you make the division? Make a note of your solutions."

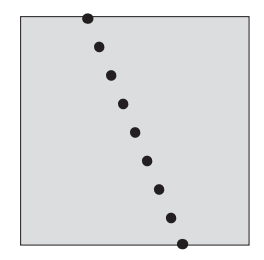

The results of the problem are published in, for example, a paper by Laine et al. (2012). The first research question in the study is: "How do pupils solve an open non-standard problem?" Pupils' solutions were categorised and classified as follows. 
Pupils' performance in solving the problem can be divided into five hierarchical levels (cf. Table 1). The lowest level is No solution (Level o), where the pupil has produced no solution during the lesson. Next is the Basic level (Level 1), where the pupil has found only the two obvious solutions (dividing with a diagonal into two triangles, and with a straight line parallel to the sides into two rectangles). The next level is labelled Straight line (Level 2), where the pupil has, in addition to the two obvious solutions, divided the square with a straight line that is neither a diagonal nor parallel to the side of the square. Finding such a solution requires a certain amount of creativity, i.e., the solver must be able to see outside of the frame of the basic solutions. There are, in fact, an infinite number of different solutions. The third level is Curved line (Level 3) where the dividing line can be arbitrarily curved, such as a fraction line or a curved line composed of arcs, whereby the solver breaks away from the barrier of the straight line. The number of such solutions is also infinite, but in this case the cardinality of potential solutions seems to be even greater than in the previous case. The highest level (Level 4) is represented by Middle point thinking, where the middle point of the square is seen as the essential element of the solutions, since all dividing lines straight or curved - go through it and are symmetrical in relation to the middle point.

Table 1. The distribution of pupils on the different achievement levels $(N=86)$.

\begin{tabular}{lllll}
\hline No solution & Basic level & Straight line & Curved line & Middle point thinking \\
\hline Level 0 & Level 1 & Level 2 & Level 3 & Level 4 \\
\hline $1(1 \%)$ & $33(38 \%)$ & $21(25 \%)$ & $18(21 \%)$ & $13(15 \%)$ \\
\hline
\end{tabular}

Most of the pupils reached levels 1-3 in their solutions, but only 13 pupils (15\%) reached the highest level (Level 4). The mode value in solutions was Level 1.

Example 3. The fourth experimental task, solved in February 2011, was "Arithmagon": "Arithmagons are specific number triangles. In arithmagons, there is a number in each corner of the triangle and their sum is between the corner numbers. Your task is to find the missing numbers in the corners. You should also explain your strategy to find the missing numbers in the case that two numbers on the sides of the triangle are the same. Additionally, construct a few arithmagons for your partner to solve."

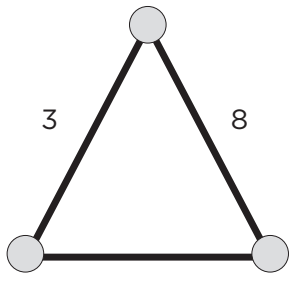


Preliminary results in the Arithmagon task are given in the published paper (Näveri, Ahtee, Laine, Pehkonen, \& Hannula, 2012). In this paper, the first research question also dealt with pupils' skill in solving such a non-standard problem.

The pupils' achievements were classified into three categories. Category A included achievements whereby pupils had come up with both a reasoning for the arithmagon solution and solvable additional arithmagons with sides with at least two of the same sums. Category B accounted for achievements in which no reasoning was provided for the solution, but pupils found additional arithmagons with sides with at least two of the same sums. In Category $\mathrm{C}$ were achievements in which pupils came up with neither reasoning nor additional arithmagons with sides with at least two of the same sums.

Furthermore, pupils' justifications for finding a solution method (i.e., Category A) when there are "two same sums" in the arithmagons were divided into three sub-classes according to the level of the justification. In the reasonings of sub-class A.1, it is clearly evident that the pupil took into account the fact that there are two same sums in the arithmagon. In the reasonings of sub-class A.2, it emerged that the pupil understood the fact that the solution was found using addition. In sub-class A.3 were those pupils who had at least tried to write something for a reasoning.

Table 2. The distribution of pupils' achievements into different categories.

\begin{tabular}{|c|c|c|c|}
\hline & Category & Example of a justification used & Number of pupils \\
\hline A.1 & $\begin{array}{l}\text { Two same sums in the arith- } \\
\text { magon, and their meaning is } \\
\text { understood }\end{array}$ & $\begin{array}{l}\text { "I pondered what +calculation is } \\
\text { needed, and always calculated the } \\
\text { same numbers, } \\
\text { e.g., } 1+1,2+2 \text { and } 4+4 . "\end{array}$ & 11 \\
\hline A. 2 & $\begin{array}{l}\text { Two same sums in the arithma- } \\
\text { gon, and understood that it is a } \\
\text { question of addition }\end{array}$ & "I only calculated +calculations." & 12 \\
\hline A.3 & $\begin{array}{l}\text { Two same sums in the arithma- } \\
\text { gon, and an unclear explanation }\end{array}$ & $\begin{array}{l}\text { "I only calculated. } \\
\text { Finally I just caught onto it." }\end{array}$ & 5 \\
\hline B & $\begin{array}{l}\text { Two same sums in the arith- } \\
\text { magon }\end{array}$ & $\begin{array}{l}\text { e.g., } 211,499,616 \text { 16, } 200500 \\
500\end{array}$ & 35 \\
\hline C & $\begin{array}{l}\text { Three different sums in the } \\
\text { arithmagon }\end{array}$ & e.g., 84 6, 59 8, 111714 & 39 \\
\hline Total & & & 102 \\
\hline
\end{tabular}

\section{Summary of the results}

In view of the results of the two examples, the first research question "How do pupils solve an open non-standard problem?" - can be answered as follows (Table 1). On one hand, the mode value of pupils' solutions was Level 
$1(38 \%)$, thus about two-fifths of the pupils only reached the basic level. On the other hand, $60 \%$ of the pupils' solutions showed some level of creativity, and as many as $15 \%$ of the pupils reached the midpoint thinking. However, we must remember that teachers guided the groups of pupils individually, and some of them may have helped their pupils more than the others.

In the second problem, about $30 \%$ of the pupils' answers included a description of a strategy (cf. Table 2), while in the rest of the answers it was only mentioned that addition is needed, and in some cases not even this was stated. Evens and Houssart (2004) claim that the skill of presenting general mathematical statements begins to develop by Grade 3 or 4 (cf. Pehkonen, 2000). It therefore seems to be important to give pupils from Grade 3 tasks in which they are compelled to explain how, based on the given information, they reach a particular conclusion, and to encourage them to explain their thinking to others (and to the teacher).

Observations based on the results presented in the present paper can be formulated as follows. Pupils (even those in Grade 3 ) have a great deal of potential that should be utilised and developed. The use of more creative tasks will develop pupils within the framework of the curriculum, as one objective of the Finnish curriculum is the development of creativity in all subjects (NBE, 2004). Pupils' reasoning skills, as demanded by the curriculum, will also be developed.

\section{Conclusion}

The Finnish curriculum demands that, in addition to calculation skills, problem solving and mathematical thinking should be taught in school (including primary school) (NBE, 2004). However, this does not seem to occur within ordinary mathematics teaching, where the teacher is too eager to use the textbook and its tasks. Therefore, new elements should be connected in instruction: open problem tasks with which the teacher can develop the pupils' problem solving and thinking skills.

In order for teachers to be able to implement such teaching, they should be interested in the development of teaching and committed to the new approach (cf. Shaw, Davis, \& McCarty, 1991). The teachers in our experimental project were clearly ready to experiment with new solutions, and some of them were genuinely interested in the possibilities of open problem solving. Some of the teachers even made significant advances in this regard, creating the impression that they are ready to use the method in the future.

The rise of constructivism focused on teachers' mathematics-related beliefs. Here, the concept belief is understood as knowledge and feelings based on 
earlier experiences. Beliefs conduct and structure every teaching and learning process. In order to change teaching-learning processes, teachers' beliefs about good and successful instruction should be developed and changed. In the literature, one finds numerous research reports on the requirements for changing and developing teachers. However, none of the described intervention methods seem to be successful without problems. What is needed, therefore, is a new understanding of the problems of change and development in teachers' professional activities (for more on the problems of teacher change, see, for instance, Pehkonen (2007)).

\section{Literature}

Anderson, J. R. (1980). Cognitive psychology and its implications. San Francisco (CA): Freeman. Becker, J. P., \& Shimada, S. (1997). The Open-Ended Approach. Reston (VA): NCTM.

Bereiter, C. (1990). Aspects of an Educational Learning Theory. Review of Educational Research, $60(4), 603-624$.

Bereiter, C., \& Scardamalia, M. (1996). Rethinking learning. In D. R. Olson \& N. Torrance (Eds.), The handbook of education and learning. New models of learning, teaching and schooling. Cambridge (MA): Blackwell.

Bergqvist, T. (Ed.) (2012). Learning Problem Solving And Learning Through Problem Solving. University of Umeå.

Blanc, P., \& Sutherland, R. (1996). Student teachers' approaches to investigative mathematics: iterative engagement or disjointed mechanisms? In L. Puig \& A. Gutierrez (Eds.), Proceedings of the PME-2o conference, Vol. 2 (pp. 97-104). Valencia: University of Valencia.

Blumenfeld, P. C., Soloway, E., Marx, R. W., Krajcik, J. S., Guzdial, M., \& Palincsar, A. (1991). Motivating project-based learning: Substaining the doing, supporting the learning. Educational Psychologist, 26(3\&4), 369-398.

Boaler, J. (1998). Open and closed mathematics: Student experiences and understandings. Journal for research in mathematics education, 29(1), 41-62.

Brown, S. I. (1997). Thinking Like a Mathematician: A Problematic Perspective. For the Learning of Mathematics, $17(2), 36-38$.

Brown, J. S., Collins, A., \& Duguid, P. (1989). Situated cognition and the culture of learning.

Educational Researcher, 18(1), 32-42.

Clarke, D. J., \& Sullivan, P. A. (1992). Responses to open-ended tasks in mathematics: characteristics and implications. In W. Geeslin \& K. Graham (Eds.), Proceedings of the PME 16, Vol I (pp. 137-144).

Durham (NH): University of New Hampshire.

Cockcroft, W. (Chair) (1982). Mathematics Counts, Report of the Committee of Enquiry into the teaching of Mathematics in Schools. London: HMSO.

Collins, A., Brown, J. S., \& Newman, S. (1989). Cognitive apprenticeship: Teaching the crafts of 
reading, writing and mathematics. In L. B. Resnick (Ed.), Knowing, Learning and Instruction. Essays in Honor of Robert Glaser (pp. 453-494). Hilldale, N. J.: Lawrence Erlbaum Associates.

Evens, H., \& Houssart, J. (2004). Categorizing pupils' written answers to a mathematics test question: "I know but I can't explain". Educational Research, 46(3), 269-282.

Kantowski, M. G. (1980). Some Thoughts on Teaching for Problem Solving. In S. Krulik \& R. E. Reys (Eds.), Problem Solving in School Mathematics. NCTM Yearbook 1980. (pp. 195-203). Reston (VA): Council.

Kwon, O. N., Park, J. H., \& Park, J. S. (2006). Cultivating divergent thinking in mathematics through an open-ended approach. Asia Pacific Education Review, 7(1), 51-61.

Laine, A., Näveri, L., Pehkonen, E., Ahtee, M., \& Hannula, M. S. (2012). Third-graders’ problem solving performance and teachers' actions. In T. Bergqvist (Ed.), Learning Problem Solving And Learning Through Problem Solving (pp. 69-81). University of Umeå.

Mason, J. (1991). Mathematical problem solving: open, closed and exploratory in the UK.

International Reviews on Mathematical Education (= ZDM), 23(1), 14-19.

Näveri, L., Ahtee, M., Laine, A., Pehkonen, E., \& Hannula, M. S. (2012). Erilaisia tapoja johdatella ongelmanratkaisutehtävään - esimerkkinä aritmagonin ratkaiseminen alakoulun kolmannella luokalla [Different ways to introduce a problem task - as an example the solving of aritmagon in the third grade]. In H. Krzywacki, K. Juuti, \& J. Lampiselkä (Eds.), Matematiikan ja luonnontieteiden opetuksen ajankohtaista tutkimusta (pp. 81-98). Helsinki: Suomen ainedidaktisen tutkimusseuran julkaisuja. Ainedidaktisia tutkimuksia 2.

NBE. (2004). Perusopetuksen opetussuunnitelman perusteet 2004 [The basics of the curriculum for the basic instruction]. Helsinki: Opetushallitus.

NBE. (2010). Esiopetuksen opetussuunnitelman perusteet 2010 [Basics of the curriculum for pre-school instruction 2010]. Retrieved from www.oph.fi/download/131115_Esiopetuksen_ opetussuunnitelman_perusteet_2010

NCTM. (2000). Principles and standards for school mathematics. Reston, VA: National Council of Teachers of Mathematics.

Nohda, N. (1988). Problem solving using "open-ended problems" in mathematics teaching. In H. Burkhardt, S. Groves, A. Schoenfeld, \& K. Stacey (Eds.), Problem Solving - A World View. Proceedings of problem solving theme group at ICME-5 (Adelaide) (pp. 225-234). Nottingham: Shell Centre. Nohda, N. (1991). Paradigm of the "open-approach" method in mathematics teaching: Focus on mathematical problem solving. International Reviews on Mathematical Education (= ZDM), 23(2), $32-37$.

Pehkonen, E. (1989). Verwenden der geometrischen Problemfelder. In E. Pehkonen (Ed.),

Geometry Teaching - Geometrieunterricht. Research Report 74 (pp. 221-230). University of Helsinki.

Department of Teacher Education.

Pehkonen, E. (1995). Introduction: Use of Open-Ended Problems. International Reviews on Mathematical Education (= ZDM), 27(2), 55-57.

Pehkonen, E. (Ed.) (1997). Use of open-ended problems in mathematics classroom. Research Report 
176. University of Helsinki. Department of Teacher Education.

Pehkonen, E. (Ed.) (2001). Problem Solving Around the World. Report Series C:14. University of Turku. Faculty of Education.

Pehkonen, E. (2004). State-of-the-Art in Problem Solving: Focus on Open Problems. In H. Rehlich \& B. Zimmermann (Eds.), ProMath Jena 2003. Problem Solving in Mathematics Education (pp. 93-111).

Hildesheim: Verlag Franzbecker.

Pehkonen, E. (2007). Über "teacher change" (Lehrerwandel) in der Mathematik. In A. Peter-Koop \& A. Bikner-Ahsbahs (Eds.), Mathematische Bildung - mathematische Leistung: Festschrift für Michael Neubrand zum 6o. Geburtstag (pp. 349-360). Hildesheim: Franzbecker.

Pehkonen, L. (2000). Written arguments in a conflicting mathematical situation. Nordic Studies in Mathematics Education, 8(1), 23-33.

Schroeder, T. L., \& Lester, F. K. (1989). Developing understanding in mathematics via problem solving. In P. R. Trafton (Ed.), New Directions for Elementary School Mathematics. NCTM 1989 Yearbook. (pp. 31-42). Reston, Va: NCTM.

Schupp, H. (2002). Thema mit Variationen. Aufgabenvariation im Mathematikunterricht. Hildesheim: Verlag Franzbecker.

Shaw, K. L., Davis, N. T., \& McCarty, J. (1991). A cognitive framework for teacher change. In R. G. Underhill (Ed.), Proceedings of PME-NA 13, Vol 2 (pp. 161-167). Blacksburg (VA): Virginia Tech. Shimada, S. (Ed.) (1977). Open-end approach in arithmetic and mathematics - A new proposal toward teaching improvement. Tokyo: Mizuumishobo. [in Japanese]

Sierpinska, A. (1994). Understanding in mathematics. Studies in mathematics education series: 2. London: Falmer.

Silver, E. (1995). The Nature and Use of Open Problems in Mathematics Education: Mathematical and Pedagogical Perspectives. International Reviews on Mathematical Education (= ZDM), $27(2)$, $67-72$.

Stacey, K. (1995). The Challenges of Keeping Open Problem-Solving Open in School Mathematics. International Reviews on Mathematical Education (= ZDM), 27(2), 62-67.

Törner, G., Schoenfeld, A. H., \& Reiss, K. M. (Eds.) (2007). Problem solving around the world: summing up the state of the art. ZDM Mathematics Education, 39(5/6), 353-551.

Wiliam, D. (1994). Assessing authentic tasks: alternatives to mark-schemes. Nordic Studies in Mathematics Education, 2(1), 48-68.

Williams, D. (1989). Assessment of open-ended work in the secondary school. In D. F. Robitaille (Ed.), Evaluation and Assessment in Mathematics Education. Science and Technology Education. Document Series 32. (pp. 135-140). Paris: Unesco.

Wu, H. (1994). The Role of Open-Ended Problems in Mathematics Education. Journal of Mathematical Behavior, 13(1), 115-128.

Zaslavsky, O. (1995). Open-ended tasks as a trigger for mathematics teachers' professional development. For the Learning of Mathematics, 15(3), 15-20.

Zimmermann, B. (1991). Offene Probleme für den Mathematikunterricht und ein Ausblick auf Forschungsfragen. International Reviews on Mathematical Education (= ZDM), 23(2), 38-46. 
Zimmermann, B. (2010). “Open ended problem solving in mathematics instruction and some perspectives on research question" revisited - new bricks from the wall? In A. Ambrus \& E. Vasarhelyi (Eds.), Problem Solving in Mathematics Education. Proceedings of the $11^{\text {th }}$ ProMath conference in Budapest (pp. 143-157). Eötvös Lorand University.

\section{Biographical note}

Erkкi Pehkonen, Dr., is a full professor (retired) in the field of mathematics and informatics education in the Department of Teacher Education at the University of Helsinki in Finland. He is interested in problem solving with a focus on motivating middle grade pupils, as well as in understanding pupils' and teachers' beliefs and conceptions about mathematics teaching.

ANu LAINe, Dr., is an adjunct professor in mathematics education, working as a university lecturer at the Department of Teacher Education at the University of Helsinki in Finland. Her research interests include affects, communication and problem solving in mathematics education.

LIISA NÄVERI, $\mathrm{PhD}$., is a researcher in the research project on mathematics education (Academy of Finland and Chilean CONICYT) in the Department of Teacher Education at the University of Helsinki in Finland. Her research interests include problem solving and understanding in mathematics learning. 